\title{
Your home, my refuge: being a refugee in Brazil
}

\author{
Hélio ARTHUR ReIS IRIgaraY ${ }^{1}$ \\ RENATA ANDERSON ${ }^{2}$ \\ FLÁVIO VELLASQUEZ ${ }^{1}$ \\ FERNANDO FILARDI ${ }^{3} 4$ \\ ${ }^{1}$ Fundação Getulio Vargas (FGV EBAPE) / Brazilian SChool of Public ANd Business Administration, Rio de JaneIRO - RJ, BRAZIL \\ 2 HEALTH IN HARMONY, PORTLAND - UNITED STATES OF AMERICA \\ ${ }^{3}$ InSTITUTO BRASILEIRO DE MERCADO de CAPITAIS (IBMEC), RIO DE JANEIRO - RJ, BRAZIL \\ ${ }^{4}$ UnIVERSIDAde FEDERAL do ESTADO do RIO DE JANEIRO (UNIRIO), RIO DE JANEIRO - RJ, BRAZIL
}

\begin{abstract}
The objective of this study was to reveal how refugees who live in Brazil perceive the macro-dynamics of the local society and how their response to them varies in accordance with their different psycho demographic profiles. We interviewed 24 refugees from different countries, genders, ages, and races. The interviews were taped, transcribed, and subjected to critical discourse analysis, resulting in three a priori categories: social, discursive, and textual practices. We found out that social practices did differ in terms of their countries of origin, gender, and race. The analysis of their discourses revealed three different places and roles: hero, victim, or faker. Finally, the textual analysis indicated the choice of words that subverted the hegemonic discourse of refugees, revealing resistance to the place refugees are relegated to in Brazilian society.
\end{abstract}

Keywords: Refugees. Gender. Social practices. Discursive practices. Textual practices.

\section{Seu lar, meu refúgio: sobre o que ser um refugiado no Brasil}

\section{Resumo}

O objetivo deste estudo foi revelar como os refugiados, residentes no Brasil, percebem a macrodinâmica da sociedade local e como suas respostas a eles variam de acordo com seus diferentes perfis psicodemográficos. Entrevistamos 24 refugiados de diferentes países, sexo, idade, raças e pele. As entrevistas foram gravadas, transcritas e submetidas à Análise Crítica do Discurso; resultando em três categorias a priori: práticas sociais, discursivas e textuais. Descobrimos que as práticas sociais diferem em termos de seus países de origem, sexo, raça e cor da pele. A análise de seus discursos revelou três lugares e papéis diferentes: herói, vítima ou falso. Por fim, a análise textual indicou a escolha de palavras que subverteram o discurso hegemônico dos refugiados, revelando resistência ao local em que os refugiados são relegados na sociedade brasileira.

Palavras-chave: Refugiados. Gênero. Práticas sociais. Práticas discursivas. Práticas textuais.

\section{Tu hogar, mi refugio: qué es ser un refugiado en Brasil}

\section{Resumen}

El objetivo de este estudio fue revelar cómo los refugiados, residentes en Brasil, perciben la macrodinámica de la sociedad local y cómo sus respuestas varían de acuerdo con sus diferentes perfiles psicodemográficos. Hemos entrevistado a 24 refugiados de diferentes países, género, edades, razas y etnias. Las entrevistas, grabadas, transcritas y sometidas a análisis crítico del discurso, dieron como resultado tres categorías a priori: prácticas sociales, discursivas y textuales. Descubrimos que las prácticas sociales diferían de acuerdo con sus países de origen, género, raza y color de la piel. El análisis de sus discursos reveló tres lugares y roles diferentes: héroe, víctima o falso. Finalmente, el análisis textual reveló la elección de palabras que subvirtieron el discurso hegemónico de los refugiados, sugiriendo resistencia al lugar al que los refugiados son relegados en la sociedad brasileña.

Palabras clave: Refugiados. Género. Prácticas sociales. Prácticas discursivas. Prácticas textuales. 


\section{INTRODUCTION}

Refugees are a specific group within international migrations; because unlike simple migrants, exiles, or (internally) displaced people, who move because of natural and ecological disasters (Black, 2001); these are individuals who are forced to flee their countries of origin as a result of wars, ethnic, religious, political, repressive regimes, and other situations of violence and human rights violations (Oliveira, 2017). Strictly speaking, these people cross borders in search of the protection of another state, with the primary objective of safeguarding their lives and freedoms. This is all they have in common.

They are not a homogeneous group for they differ in gender, age, skin complexion, place of origin, and sexual orientation. Indeed, they come from different cultures, speak different languages that most of the time are totally different from the host country's; moreover, not all of them are granted refugee status; thus, they are forced to live on a temporary-residence visa, which does not allow them to work (Gabriel, 2003).

Refugees are traumatically dislocated from their homeland, where they are familiar with physical, economic, social, political, legal, and cultural contexts (Dykstra-Devette \& Canary, 2019). In an alien environment, they have to reinvent their social identities and find new meanings for their lives (Nguyen, 2012). These individuals have to cope with painful losses and physical and emotional hardships (Hardy \& Phillips, 1999). In addition, they must learn how to respond to the macro dynamics of the dominant society in which they have been relocated (Hamid, 2012).

How do refugees, of different psycho demographic profiles, perceive these dynamics and respond to them in Brazil? This is our research question.

The relevance of this study lies on the fact that, although the refugee crisis in Europe has been widely documented (Spiegel, Checchi, Colombo \& Paik, 2010; Turner, 2019); nevertheless, there is a gap in the literature concerning the refugees' crisis in other countries, such as Brazil (Alawa \& Parmida, 2019; Silva, 2019), where the number of refugees, as well as their countries of origin, has multiplied tenfold in the past five years (Comitê Nacional para Refugiados [CONARE], 2019).

Besides, most previous studies have focused on the skyrocketing cases of xenophobia (Dotti, 2020), hate discourses (Lepoutre, 2017), and the election of right-wing parties (Öztürk \& Pickel, 2019), but always treating refugees as a homogeneous group; thus Rizkalla and Sega (2019) suggested that further investigations are needed on the diversity of the group.

In order to fill this gap, we have designed empirical research. We have interviewed refugees, from different countries, genders, ages, and sexual orientations, who live here in Brazil. These interviews were transcribed and subjected to critical discourse analysis and, to discuss our findings, we have structured a theoretical framework which addresses the main pillar of the Brazilian society and the individual strategies to cope with adversities.

\section{CONTEXTUALIZATION}

\section{Brazil, a country for all: the founding myth of Brazilian society}

The founding myth of Brazilian society taught in schools, propagated by the media, and accepted as common sense, is that the country was discovered by the Portuguese, who, when they arrived here in caravels, found a paradise inhabited by Indians. In a receptive contact, a barter begins between Brazilian wealth (spices, wood) and European objects (mirrors, combs, knives). In addition, they use indigenous labor to bring Africans to work. With the European's interest in owning the land, many began to arrive in Brazil with their families, animals, clothes, books, customs, their way of thinking and doing things (Chauí, 2000).

In this fantasy, Brazil is defined as a blessed land, a rediscovered paradise, which has a peaceful, orderly, generous, cheerful, and sensual people, even when suffering; a country without prejudice, which ignores the discrimination of race and creed, aiming to call itself a "racial democracy" (Franco \& Prado, 2011). 
Throughout history, the practice of miscegenation has been seen as a pattern that fortifies the breed; a welcoming country for all who wish to work there (Barreto, 2004). In this sense, in the country, there are huge colonies of Portuguese, Italians, Spanish, Japanese, Lebanese, Chinese, Poles, Ukrainians, Swiss, Dutch, Finns, and even Americans who fled the civil war in the $19^{\text {th }}$ century (Camargo, 2003).

As in postcards, where you can see Christ the Redeemer, Brazil welcomes everyone with open arms; only those who do not work do not improve and only those who do not work do not progress, and there is, therefore, no discrimination of class, race, or skin color, but rather a repudiation of vagrancy, which, as is known, is the mother of delinquency and violence; it is a regional "country of contrasts" (Camargo, 2006), therefore intended for economic and cultural plurality. Brazilians are proud to be defined as a "cordial man" (Ribeiro, 2010), whose treatment, hospitality, and generosity are traits that are recognized by all foreigners who visit the country.

But do refugees have the same experience? What are their strategies to adapt to their host country?

\section{THEORETICAL FRAMEWORK}

\section{Individual strategies}

Individuals, like organizations, are not separate entities from the environment; on the contrary, they are united and linked in the process of a mutual constitution (Giddens \& Sutton, 1989). From this perspective, individuals are inserted in a system of relationships structured by standardized and articulated activities, which express social norms and rules (Tsui-Ausch, 2005). Then, a social arena is established (Ernst \& Jensen, 2019), impregnated by the environment (Granovetter, 1985), removing from it and transmitting, in reciprocal interaction, norms and patterns of behavior that constitute adequate modes of action.

In this study, these modes of action are the survival strategies that refugees adopt to survive in the host country, from living in a closed community, mingling with Brazilians, and trying to pass off as one of them or even confronting and reinforcing their national identities (wearing typical clothes, for instance). When these strategies are successful, mimicry occurs, that is, they are copied by other individuals (Alvesson \& Robertson, 2016).

Nevertheless, it is not being suggested here that the elaboration of survival strategies is an exclusively rational process, conceived by an homo economicus (Husted, 2007), who, imbued with rational omniscience, is able to deal with the real world from an objective point of view and face all its complexity.

This study is based on the belief that individual behavior is modeled by standards created and shared in interaction, but incorporated in the form of objective norms and rules, crystallized in society as legitimized conceptions about the most effective way in which organizations operate (Ernst \& Jensen, 2019); i.e, refugees are social actors, individuals who assume an identity, and whose characteristics are socially constructed according to the expectations of external groups about who he is and the way he must face the situations.

\section{Immigrants and refugees in Brazilian society}

The negative status, historically associated with immigration and refuge (Sayad, 1998), is a factor that generates discrimination. Although suffering and pain are inherent to all human beings, the decision to emigrate or take refuge is still a largely male issue (Organização Internacional do Trabalho [OIT], 2015). In fact, women migrate less than men for work reasons and more because of family ties (usually, in relation to a man) than for any autonomous reasons (Moreira, 2018).

Therefore, when studying refugees and immigrants, it is essential that the issue of gender is addressed, given that the experiences tend to be considerably different. The gender issue for immigrant and refugee women runs through gender roles in their country of origin and in the host country (Medeiros-da-Silva, Auoar, Pereira-Da-Silva \& Modesto-de-Oliveira, 2020).

When analyzing the differences between men and women, it is important to distinguish between two distinct categories: biological sex and gender itself. The former includes only the physiological part of human body, being determined at birth and not being able to be changed by natural procedures; the latter includes features established by society as a construct. 
Although the studies reveal there are no automatic relationships between biological sex and the prerogatives of a gender (Andrijasevic \& Rhodes, 2019), the attempt at justifying masculine and feminine traits according to natural criteria had reinforced the gender inequality, thus resulting in many disruptive consequences, mainly in terms of social relations and sexual division of work.

Bourdieu defines gender as sexed habitus. Understanding this sociological concept as the way a group of individuals, who shares a similar cultural capital, think and acts (Bourdieu, 1977), the author perceives, just as the other kinds of habitus, that gender is imposed by social agents such as Work, Family and School, therefore the group of characteristics defining masculine and feminine are socially constructed. Finally, as a habitus, it is not possible for an individual to easily change from a type of habitus to another without retaliation from society, so this would explain why a more masculine woman or a feminine man can be so discriminated where they live.

Gender has been basically constructed on the reproductive function of women, resulting in distinct work division comparing to men, the providers. Bourdieu (2007) argues that men have been associated to the public space and the following personality traits: aggressiveness, competition, rationality, independence, and strength; whereas, women have been related to home and, historically, depicted as caring, cooperative, emotional, dependent, and fragile. Hence, the workforce desired attributes and valued by the market - such as aggressiveness, competition and rationality are masculine (Kimmel, 1994), what is a disadvantage per se for women.

This sexist perspective prevails in most of Latin America, including Brazil (Olivius, 2016); thus, as well as local citizens, who face invisible barriers to entry and rise in the labor market (Hryniewicz \& Vianna, 2018), immigrant and refugee women do not share the same opportunities and privileges as their male peers (Pereira \& Abreu, 2016), due to the patriarchal construction of the society in question (Knappert, Kornau \& Figengül, 2018).

In fact, in Brazil, the labor market tends to be more accessible for a refugee man than for a refugee woman (Cheung \& Phillimore, 2017; Pereira \& Oliveira, 2017). Women have been relegated to informal jobs, such as the informal trade in food (usually from their countries of origin), clothing or handicrafts (Mountian, Gomes \& Carvalho, 2020).

Regarding the formation of a network of contacts and cooperation in the context of migration, there is also an important crossing related to gender. Studies suggest that immigrant and refugee men have easier socialization and, consequently, create a network that can facilitate access to education and work (Versiani \& Carvalho, 2018). Women, on the other hand, although they have access to education and training, they have limited access to the formal job market in Brazil due to the country's economic dynamics (Miltersteiner, 2018), to the glass ceiling (Santos, Tanure \& Carvalho, 2014), or even to the restriction of freedom of movement caused by fear of being victims of urban violence or xenophobic attack (Villen, 2015).

In fact, there is evidence that these foreign women tend to be more morally and sexually harassed than their Brazilian counterparts, as local men believe that they will not able to vocalize aggressions out of fear of the unknown society, for not knowing their rights, for not being fluent in Portuguese, and not mastering the cultural codes of the host country, which would make it easier for their aggressors to disqualify any complaints they made (Tedesco, 2010).

\section{RESEARCH DESIGN}

This study was illuminated by the ontological perspective of critical postmodernity, which analyzes society from a non-patriarchal perspective, that is, the focus of discussion has shifted to other dimensions, democracy, and multiplicity, starting from the premise that there are multiple voices, living in multiple realities (Boje, 1991).

This study is based on the assumption that the understanding of the meanings of social actions must start from the perspective of the subjects themselves, and not from the researcher's point of view.

In order to collect the data for this research, we mobilized a large group of stakeholders: NGO's, the Catholic church, MSF, intermediary organizations, civil societies, as well as refugee and asylum-seeking communities. 
We considered the first of these groups to be the project's main beneficiaries and identified a number of inclusion criteria. The first of these was to be a refugee, asylum seeker, or undocumented migrant aged between 15 and 60 years old. Second, respondents had to be living either in Rio de Janeiro or São Paulo. Using the snowball technique, we ended up interviewing 24 subjects as described in Box 1.

Box 1

Interviewees' profiles

\begin{tabular}{|c|c|c|c|c|c|}
\hline Interviewee & Gender & Age & Skin complexion / Race & Country of origin & $\begin{array}{c}\text { Residence Status } \\
\text { in Brazil }\end{array}$ \\
\hline Alpha & $\mathrm{F}$ & 28 & White & Colombia & Legal \\
\hline Beta & M & 30 & Brown / mixed & Argentina & Legal \\
\hline Charlie & $\mathrm{F}$ & 29 & $\begin{array}{c}\text { Brown / indigenous } \\
\text { Andean }\end{array}$ & Colombia & Illegal \\
\hline Delta & $\mathrm{F}$ & 38 & Black & Colombia & Legal \\
\hline Echo & $\mathrm{F}$ & 40 & White & Colombia & Legal \\
\hline Fox & $\mathrm{F}$ & 29 & Black & Angola & Legal \\
\hline Golf & $\mathrm{F}$ & 27 & Black & $\begin{array}{c}\text { Democratic Republic of } \\
\text { Congo }\end{array}$ & Illegal \\
\hline Hotel & M & 32 & Black & $\begin{array}{c}\text { Democratic Republic of } \\
\text { Congo }\end{array}$ & Illegal \\
\hline India & M & 31 & White & Syria & Legal \\
\hline Kilo & $\mathrm{F}$ & 26 & Black & Mozambique & Illegal \\
\hline Lima & M & 38 & White & Syria & Legal \\
\hline Mike & $\mathrm{F}$ & 34 & Black & Gambia & Legal \\
\hline November & $\mathrm{F}$ & 33 & Black & Guinea Bissau & Illegal \\
\hline Oscar & M & 28 & White & Venezuela & Legal \\
\hline Papa & $\mathrm{F}$ & 31 & White & Syria & Illegal \\
\hline Quebec & M & 29 & Black & Venezuela & Legal \\
\hline Romeo & $\mathrm{F}$ & 33 & White & Palestine & Legal \\
\hline Sierra & M & 37 & Black & Venezuela & Illegal \\
\hline Tango & M & 27 & Black & Venezuela & Illegal \\
\hline Uniform & $M$ & 26 & White & Syria & Illegal \\
\hline Victor & $M$ & 26 & $\begin{array}{c}\text { Brown / } \\
\text { indigenous Andean }\end{array}$ & Bolivia & Legal \\
\hline Whisky & $\mathrm{F}$ & 33 & $\begin{array}{c}\text { Brown / } \\
\text { indigenous Andean }\end{array}$ & Bolivia & Legal \\
\hline Yankee & M & 28 & Black & Haiti & Legal \\
\hline Zulu & $\mathrm{F}$ & 26 & Black & Haiti & Legal \\
\hline
\end{tabular}

Source: Elaborated by the authors.

The respondents were, a priori, informed of the purpose of the research, as well as guaranteed anonymity and confidentiality of their reports. The interviews per se were structured in two parts: a) the collection of the categorical data of the interviewees (gender, age, country of origin) and b) a conversation about their life trajectories (Cavedon \& Ferraz, 2003). They were only considered valid when informed consent had been given and when the taped interview matched the notes that we had taken.

The interviews were transcribed and submitted to the Critical Discourse Analysis (Fairclough, 2008), a paradigm established within linguistics (Wodak, 2004), which adopts a critical dimension about language, which is considered a determinant for social transformation and for understanding the way social and ideological practices are produced, reproduced and naturalized. 
The basic premise of the CDA is that the discourse has constitutive power since it forges knowledge, values, and paradigms, as well as being a pillar in the construction of social relationships and identities. Under this view, discourse and narratives are produced and reproduced in a circular process, in which social practices are a structuring factor in the construction of texts; while these, in turn, influence society, shaping the views of those who read or consume them (Fairclough, 2008).

In this way, criticizing is "making the interconnection of things visible" (Fairclough, 1995, p. 36), adopting an explicit political position, and focusing on self-reflection (Wodak, 2004). Indeed, the discourse "is more than just the use of language: it is the use of language, whether spoken or written, seen as a type of social practice". In this way, it is not limited to a simple communication tool; strictly speaking, it is a social practice, and for that reason, discourse and social structures maintain complex influential relationships.

\section{FINDINGS}

Foreigners who live in Brazil are classified into five categories: visitors, legal residents (temporary or permanent), asylum-seekers (who are granted a temporary visa), refugees, and illegal aliens. Despite their residence status, all of them are entitled to use the National Health Medical Services (SUS), which means free consultations and operations. These benefits were the key decision-factor for Charlie and Whisky choosing Brazil, in spite of the language barrier.

In this study, we have focused on the refugees, who live in the country legally and illegally, that currently totals 1.2 million people (CONARE, 2019), who mostly come from Venezuela (27\%), Syria (23\%), Haiti (14\%), The Democratic Republic of Congo (9\%), Colombia (7\%), among others. In terms of gender, $72 \%$ are male and $28 \%$, female. Most of them are between $25-45$ years of age ( $27.8 \%$ of the men and $14.64 \%$ of the women) (CONARE, 2019). These people also differ in race, skin complexion, religion, and social backgrounds.

The emergent categories from the discourses were interpreted and grouped into three major dimensions, as proposed by Fairclough (1989): the social, the discursive, and the textual practices.

\section{Refugees and the social practices: the beans and the dream}

In this first group, we focused on the role of the social and historical context as a regulating factor in the process of production, circulation, and reception of the speeches. Analyzing the dimension of social practices is essential, since they are embedded in concrete material social structures, directly influencing the discursive constitution of society, since it "does not emanate from a free play of ideas in people's heads" (Fairclough, 2008, p. 93).

The social practices of the refugees' discourses were centralized in the conflict between "the beans and the dream". Here, we are using as a metaphor a novel written by Orígenes Lessa about Campos Lara, who lives in a rural small town with his wife Maria Rosa and their children and works as a teacher. Campos Lara is a poet and tends to forget matters of practical nature in favor of his intellectual reveries. Whereas he feels isolated, living in a forgotten place, without anyone with whom to discuss his thoughts, his wife struggles to keep their house from falling apart and their children from starving.

The refugees came to Brazil, drawn to the dream of Brazil as a blessed land, a rediscovered paradise, which has a peaceful, orderly, generous, cheerful, and sensual people, even when suffering; a country without prejudice, which ignores the discrimination of race and creed, aiming to call itself a "racial democracy" (Chauí, 2000; Franco \& Prado, 2011). Getting here, they are challenged with another reality - the bean - of a people with selective hospitality and a country where xenophobia and racism are not rare.

For instance, Papa and Uniform, who have been living in Brazil for the past three years, but are still in the process of being legalized, make a living selling Arabic food and sweets in the streets of Copacabana. Their stall was attacked by a group of Bolsonaro's support telling them to "go back to the pit they came from". Uniform was called a "terrorist", whereas Papa, a "weirdo", dressed like Mancha Negra (The Phantom Blot, in English).

This interview, when compared with the others, highlighted the surge of a "New Brazil", since the ultra-conservative president (Jair Bolsonaro) was elected in 2018. This new social arena, configured by a xenophobic discourse, which is now more socially accepted, was pointed out in most interviews. Most refugees affirmed that they have already been told to go back home. 
For example, Sierra and Tango told us about the experience they had last Christmas, while at the subway exit in Copacabana, where they sell bric-a-brac. They were confronted by two Brazilian black ladies, who lived in a slum nearby and who also sell things at the same place; they were outraged that those "black foreigners" were competing with them. It is clear that there is neither class nor race solidarity. Although these ladies are discriminated against on account of gender, social class, and skin complexion, in the Brazilian society, they reproduced the same discourse; expressing xenophobia.

On the other hand, Delta, who also witnessed xenophobic attacks, has elaborated a rational survival strategy (Hused, 2007). She has suffered prejudice on account of her skin color [black], which surprised her, because as she stated "I never expected Brazil to be this racist because it sells an image of a tropical paradise, where miscegenation had succeeded". This discourse fragment reinforces the previous studies (Barretto, 2004; Chauí, 2000; Ribeiro, 2010) on the social construction of the national identity.

However, living with and observing other blacks in Brazil, helped her to reckon a successful survival strategy (Alvesson \& Robertson, 2016), by mimicking them. She explained that once "there was a group of Venezuelans selling handicrafts on the beach and they suffered severe reprisals from the police and people who were passing by (Brazilians), including hate speech. As I am black, I went unnoticed, pretending to be a Brazilian". The lexical selection "pretending to be a Brazilian" denotes how Delta, as a social actor, assumed an identity, whose characteristics are socially constructed according to the expectations of the main external group, to go through a critical situation (Ernst \& Jensen, 2019).

The social practices that regulated the production of our interviewees' speeches showed no distinction whatsoever regarding their status - legal or illegal - in the host country; but did differ in terms of their countries of origin, gender, race, and skin complexion.

Those who came from South American and Portuguese-speaking countries in Africa had expected to have a smoother adaptation process to Brazilian society.

Beta, for instance, explained that he was aware of the rivalry in soccer, but he knew that Brazilians would always refer to Argentinians as "hermanos" (brothers). Those who came from Colombia (Alpha, Charlie, Delta, Echo), Venezuela (Oscar, Sierra, and Tango) and Bolivia (Victor and Whisky) knew that they would face a language problem; because, despite the similarity, Portuguese-speakers can understand Spanish, but not the other way around; and those who came from Angola (Fox), Mozambique (Kilo) and Guinea Bissau (November) were confident that they would easily communicate with Brazilians.

All these interviewees judged they came from similar societies (culturally speaking) and that it would not be a problem to decipher the minor differences they would encounter, especially because they expected to count upon the "friendliness" and "hospitality" of their guests.

Charlie a single-mother of a one-year baby girl, explicitly stated that she "never expected to face any prejudice in Brazil, neither for being a street vendor, nor for being Colombian or woman", but she noticed that life would be not that easy when she was stopped by a social worker in the city of São Paulo, who wanted to take the baby into custody. Charlie, very tense and with tears in her eyes, said that the social worker, who was a nisei or sansei (Japanese origin), was clearly authoritarian, and claimed several times that people like Charlie came to Brazil only to use the country's social and health services, giving nothing in return, and worked polluting the streets and using child labor to attract clients out of pity; thus she (the social worker), had to be assured that the infant was not being mistreated.

The social worker's discourse was constructed upon which social practice? Xenophobia? Racism, for Charlie has Andean features? Discrimination against informal workers?

The lexical selection "people like you" strongly suggests racism because, according to Charlie, she "felt" that it was discrimination against the way she looked; and xenophobia because she noticed rancor in the social worker's voice when she said, "come to Brazil only to use the country's social and health services".

Very specifically, India and Lima denounced practices of Islamophobia, because they were attacked on account of their religion, and addressed as "terrorists". Their aggressors were women, dressed in evangelical dresses, who shouted that there was no place for them here, "a country that belonged to Jesus Christ, the Savior".

Zulu, despite being Haitian, heard that she had to go back to Africa, because "there are already too many negros in Brazil". Although the word negro does not have the same aggressive and derogative meaning as in English - as a matter of fact, the black movements use "negro" as a way of stressing their pride - the lexical selection "there are already too many" infers a racist statement. 
Delta, Kilo, and Quebec have some black Brazilian friends and they reckon that racism is stronger than xenophobia, for their native counterparts share the same perspective of being discriminated against on account of their skin complexion, what is still a source of social stigma in Brazilian society (Camargo, 2006). Oscar, for instance, has stated that "for being white he could pass off as a good Brazilian". The lexical selections "white" and "good" reveal how skin complexion is associated to social status in the host society.

However, gender plays a key role in the social-practice dimension of these violent discourses and hate speeches. Although male refugees are also targets of aggression, they tend to be less directly confronted and physically threatened than women, who feel more fragile and usually hear sexual offenses and threats.

Indeed, Sierra and Tango, who entered Brazil through the northern border of Roraima, told us that women and the female transgenders who were in their group were more intimidated by the Brazilian border police and demanded sexual favors to have their admittance to the country facilitated. While living in Boa Vista, the capital city of Roraima, still under a temporary visa and without access to government funding, they (the male) would perform small services; whereas the women and transgenders were sometimes forced into prostitution (by the police) and the children were offered to be bought or used as cheap domestic labor.

It is important to highlight that in Brazil, even middle-class families have maids and domestic servants, who are used to work informally; i.e. without the document called "Carteira de Trabalho", which assures the workers' one-month-paid vacation a year, a $13^{\text {th }}$ salary, retirement after 25 years of service (women), and also a 30\%-bonus on the vacation month. However, about 5 years ago, the government approved a law that domestic servants had to be documented, which increased the costs for having one. Undocumented immigrants proved to be a substitute for them; especially women, who are expected to clean, cook, babysit, and work 12 hours a day, 6 days a week, with none of the legal rights documented workers have. Tango even reported that he had heard of women whose passports were held by the bosses.

Women of different countries, ages and skin complexions have denounced that they were discriminated against on the base of gender. Several times they were questioned about having a husband or a father that would be responsible for them.

Sexism, xenophobia, and racism, although being intrinsic to the Brazilian society historically (Chauí, 2000), was denounced and exposed by the refugees.

But how are these social practices reflected in the discursive practices (Fairclough, 2008)?

\section{Refugees and the discursive practices: the meaning beyond the words}

The discursive practice aims at explaining the dynamics of social-practice processes, in particular, institutional contexts. At the limit, their analysis seeks to unveil how intertextual and interdiscursive regulation, as well as the constitution of discourses and narratives, takes place, in specific communicative circumstances (Fairclough, 2008).

This analysis allows us to assess the role of the sender; because, when it ignores the broader game (Fairclough, 1992), namely, the economic, social, political, and historical arena in which it is inserted, and in which it inevitably - even if involuntarily participates, it can (re) produce a discourse, collaborating for institutionalization, reproduction, and naturalization of power relations (usually asymmetric) (Fairclough, 1995).

In this study, the question - concerning the discursive practice - is in which social place do the refugees perceive themselves in the host country?

The analysis of their discourses revealed three different places and roles: hero, victim, or faker.

Heroes, because some of them were proud of their trajectory, the way they left their home countries, (walks through the jungle, clandestine on ships) and even facing the hardships in Brazil how they can still send money to their families in their home countries. Uniform, for instance, told us how his family talks about him in Syria and how he is their only hope to get out of the war zone and bring them to a safe haven.

Others see themselves as victims of an unfair economic system or political regime in their home countries. For instance, Golf, Hotel, Papa, and Tango accused the United States and the colonist Europeans of exploiting their homeland and provoking a civil war that forced them to flee away; thus, they felt "trapped in a plot in which they could do nothing, but suffer". 
Living in Brazil has not changed the way they see themselves. In many discourses, they related that they felt betrayed by a fake promise. Yankee and Zulu told us that the Brazilian force operatives that controlled Haiti claimed that Brazil was a very hospitable and prosperous country; that the Haitians would live a much better life if they migrated; besides, it would be easy to get a permanent visa.

Indeed, these interlocutors understood that Brazil was a rich and powerful country, that had invaded and "annexed" Haiti; therefore, "we have the right to move to the metropole as a citizen, with all the rights and benefits". Nevertheless, life as a refugee has not been easy: after years they are still living on a temporary working visa, the government does not have any specific policy to help the adaptation or even to learn the language.

For instance, Yankee and Zulu explained that they fled Haiti on a boat to Guatemala, and they had to hike and walk across Central and South America in order to enter Brazil over the western border in Acre (a very poor state in the Amazon), where they lived for two years. Zulu said that she felt like "a mocinha da novela sem final feliz". This lexical selection refers to the typical female protagonist of a Latin-American soap opera, who usually suffers throughout the story until she finds a happy ending; but Zulu expects not to have one ("sem final feliz"; i.e; without a happy end). "Life is not a soap opera", as she said.

Throughout the interviews, we noticed that women tend to be more romantic in the narratives; despite being more pessimistic than their male counterparts. Males chose words to demonstrate how strong they are, and value their masculinity; notwithstanding, their facial expressions transmitted despair and anguish.

Finally, a few interlocutors perceive their social place as fakers, because they have to pass off as something or someone they are not. Delta was one of them, for having used being black as a survival strategy (Hused, 2007).

Romeo, for example, has the same feeling, because he lies about his academic background in order not to be seen as overqualified when applying for a job. Romeo is a physician, and although he is a legal resident, he cannot exercise his profession, because his diploma has yet to be recognized in Brazil, which may take years due to the bureaucracy. He has worked as a handyman and in his LinkedIn profile, he omits his professional qualification. Romeo said that he felt bad about it: "I feel like I am lying to everyone and this is not what Allah demands from us".

Gender, race, and skin complexion did not seem to be relevant in the construction of the discursive practices. The refugees' social places are a mix of pleasure and pain; pride and shame; hope and despair; but how are these discursive practices reflected in the textual practices? (Fairclough, 2008).

\section{Refugees and the textual practices: choosing the words to express my feelings}

Finally, there is still textual practice, which corresponds to the linguistic and textual dimension of the discourse per se (Fairclough, 2008).

The purpose of analyzing this practice is not merely to describe the abstract linguistic system - la langue (Saussure), nor the lexical, syntactic, and textual properties of a discursive production (Fairclough, 1992).

At the limit, in this dimension, we seek to expose the extent to which lexical selections, syntactic constructions, the use of cohesive mechanisms, the distribution of speech shifts as well as, the mobilization of certain arguments facilitate reproduction (or subversion) hegemonic discourses, and the naturalization of certain ideologies and practices, which, in a mimetic way, promote the maintenance and strengthening of power relations (Fairclough, 1995).

In Fairclough's CDA (2008), the analysis of the textual dimension conducted based on Halliday's systemic-functional linguistics, focuses on the following aspects of the text: vocabulary, grammar, cohesion, and macro textual structure (Halliday, 1985).

Indeed, throughout the interviews, our interlocutors used words that subverted the hegemonic discourse of refugees, revealing resistance to the place they were relegated in Brazilian society. We understand resistance as a social phenomenon which is reified as actions of conformity, confrontation, rebellion, retaliation, and even resilience; however, these actions are not necessarily mutually exclusive when viewed from an ontological perspective in which subaltern relationships are neglected, denied, and silenced (Alvesson \& Robertson, 2016).

The choices of words to express resistance - in its multiple perspectives - suggested much more than a simple reaction or response to the actions, physical and verbal aggressions that our interlocutors have suffered. It was a response to an action and a new action, with its own course and the possibility of affecting the action of others (Hused, 2007). 
However, resistance does not need to be active and violent. On the contrary, non-violent and passive forms of resistance are, in general, more effective because violence tends to undermine the resistance forces (Ernst \& Jensen, 2019), and this was the most common survival strategy adopted by women, in opposition to men. For instance, Papa said that she is still a Muslim woman, who does not agree on many Brazilian cultural and social habits and behavior, but she pretends she does, because "pretending that everything is okay and not changing our inside is the smartest thing to do".

The analysis of the words that our interlocutors have chosen made visible the invisible; i.e, how the psycho demographic traits influence their perceptions, narratives, the way they express their feelings.

We reckon that the mechanisms that produce such invisibility or distorted the visibility of the refugees' reality must be brought to light. This must necessarily include the critical reflections of the 'invisible' people themselves and reflect on the Brazilian society's values and practices that are hidden under the cover of a would-be hospitable country that welcomes everyone and does not discriminate based on gender, race, and skin complexions.

\section{DISCUSSION AND CONCLUSIONS}

In this study, we sought to reveal how the refugees, who live in Brazil, perceive the macro dynamics of the local society and how their response to them varies in accordance with their different psycho demographic profiles.

Firstly, deconstructing the myth of Brazil as a hospitable country and a racial democracy through the refugees' eyes, reinforced the evidence that the foundations of Brazilian society indeed lies upon the model of a patriarchal family and which has established rigid (almost) inflexible moral paradigms of conduct that create a barrier for foreigners to overcome, as well as social codes can be difficult to be deciphered.

These social behaviors have regulated the relationships between the locals and the refugees, defining the norms of domination, entrusting the centralization of power to the hands of those who dominate the social arena, as well as the subordination of those who do not.

The three dimensions of the three-dimensional model of Fairclough (2009), which we used to analyze the data, suggested that the choice of a certain syntactic construction (textual practice) comes from the way the interlocutors represent themselves or a specific activity (discursive practice), and also that it is regulated by power relations and ideologies that structure society (social practice).

Finally, analyzing the psycho demographic differences among the refugees we have identified challenges for academia, the Brazilian government, and society.

In academia, we must not neglect the difference of what may seem to be a homogeneous group, for it may compromise and jeopardize our researches.

The Government, by its turn, must rethink and reconsider the current policies for the refugees and asylum-seekers, in terms of speeding their residence visas, take into consideration their different backgrounds and origins to give the proper familiarization-and-integration training (which currently do not take into account these peculiarities), as well as redesign the health programs for this group to adequate the protocol to the refugees' specific needs, especially in terms of gender and the pathologies they may have or develop on account of their origin and life story.

The Brazilian society, at last, must come to terms with its historical and social practices, not only concerning refugees but all minority groups (in terms of economic capital, not numbers) - women, blacks, indigenous peoples and LGBTQIA+ individuals - in order to construct a truly democratic nation. 


\section{REFERENCES}

Alawa, J., Zarei, P., \& Khoshnood, K. (2019). Evaluating the provision of health services and barriers to treatment for chronic diseases among Syrian refugees in Turkey: a review of literature and stakeholder interviews. International Journal of Environmental Research and Public Health, 16(15), 2660.

Alvesson, M., \& Robertson, M. (2016). Organizational identity: a critique. In M. G. Pratt, M. Schultz, E. A. Blake, \& D. Ravasi (Eds.), The Oxford handbook of organizational identity. Oxford, UK: Oxford University Press.

Andrijasevic, R., Rhodes, C., \& Yu, K.-H. (2019). Foreign workers: on the other side of gendered, racial, political and ethical borders. Organization, 26(3), 313-320.

Barretto, M. (2004). Relações entre visitantes e visitados: um retrospecto dos estudos socioantropológicos. Revista Turismo em análise, 15(2), 133-149.

Beauvoir, S. (1995). O Segundo Sexo. Rio de Janeiro, RJ: Nova Fronteira.

Black, R. (2001). Fifty years of refugee studies: From theory to policy. International migration review, 35(1), 57-78.

Bourdieu, P. (1977). Sur le pouvoir symbolique. Annales Interscience, 32(3), 405-411.

Bourdieu, P. (2007). A dominação masculina. Rio de Janeiro, RJ: Bertrand Brasil, 2007.

Camargo, L. O. L. (2003). Os domínios da hospitalidade. Hospitalidade: cenários e oportunidades (pp. 61-71). São Paulo, SP: Pioneira Thomson Learning.

Camargo, L. O. L. (2006). Hospitalidade sem sacrifício? O caso do receptivo turístico. Revista hospitalidade, 3(2), 11-28.

Carrigan, T., Connell, B., \& Lee, J. (1985). Toward a new sociology of masculinity. Theory and society, 14(5), 551-604.

Chauí, M. S. (2000). Brasil: mito fundador e sociedade autoritária. São Paulo, SP: Editora Fundação Perseu Abramo.

Comitê Nacional para Refugiados. (2019). O que é refúgio. Brasília, DF: Secretaria Nacional de Justiça. Retrieved from https://www. justica.gov.br/seus-direitos/refugio

D’Angelo, A., \& Kofman, E. (2018). From mobile workers to fellow citizens and back again? The future status of EU citizens in the UK. Social Policy and Society, 17(2), 331-343.

Dotti, G. (2020). Racismo, xenofobia e migração na Itália, um país pós-católico. The Ecumenical Review, 72(1), 37-47.

Dykstra-DeVette, T. A., \& Canary, H. E. (2019). Crystalline empowerment: negotiating tensions in refugee resettlement. Organization Studies, 40(3), 323-342.

Ernst, J., \& Jensen, A. (2019, June). Organizational identity struggles and reconstruction during organizational change: narratives as symbolic, emotional and practical glue. Organization Studies, 017084061985448. Retrieved from https://doi.org/10.1177\%2F0170840619854484

Fairclough, N. (1992). Discourse and social change. Cambridge, UK: Polity press.
Fairclough, N. (1995). Critical Discourse Analysis. London, UK: Longman.

Fairclough, N. (2008). Discurso e mudança social. Brasília, DF: Editora Universidade de Brasília.

Foucault, M. (1984). As palavras e as coisas: uma arqueologia as ciências humanas. São Paulo, SP: Martins Fontes.

Franco, P. S., \& Prado, J. (2011). A hospitalidade e a cordialidade: reflexões sobre o Brasil. Retrieved from www.periodicodeturismo. com.br/site/artigo/pdf/A_hospitalidade_e_cordialidade2.pdf

Gabriel, Y. (2003). Your home, my exile: boundaries and otherness' in antiquity and now. Organization Studies, 24(4), 619-63.

Giddens, A., \& Sutton, P. W. (1989). Sociologia. Cambridge, UK: Polity.

Granovetter, M. (1985). Ação econômica e estrutura social: o problema da imersão. American Journal of Sociology, 91(3), 481-510.

Hamid, S. C. (2019). (Des)integrando refugiados: os processos do reassentamento de palestinos no Brasil. Brasília, DF: Editora Universidade de Brasília.

Hardy, C., \& Phillips, N. (1999). No joking matter: discursive struggle in the Canadian refugee system. Organization Studies, 20(1), 1-24.

Hryniewicz, L. G. C., \& Vianna, M. A. (2018, junho). Mulheres em posição de liderança: obstáculos e expectativas de gênero em cargos gerenciais. Cadernos EBAPE.BR, 16(3), 331-344.

Husted, B. W. (2007). Agency, information, and the structure of moral problems in business. Organization Studies, 28(2), 177-195.

Irigaray, L. (2001). Thinking the difference: For a peaceful revolution. Londres, UK: A\&C Black.

Kant, E. (1964). Anthropologie du point de vue pragmatique. Paris, France: Vrin.

Kimmel, M. S. (1994). Homophobia, Masculinity. Fear, shame, and silence in the construction of gender identity. In H. Brod \& $\mathrm{M}$. Kaufman (Eds.), Theorizing Masculinities (pp. 213-219). Chicago, IL: University of Chicago Press.

Lepoutre, M. (2017, October). Hate speech in public discourse: a pessimistic defense of counterspeech. Social Theory and Practice, 43(4), 851-883.

Medeiros-da-Silva, P., Auoar, W., Pereira-Da-Silva, A., \& Modestode-Oliveira, W. (2020). Os desafios da integração de refugiados em suas experiências de trabalho nas organizações. In Anais do 44을 Encontro de Gestão de Pessoas e Relações de Trabalho, Curitiba, PR.

Miltersteiner, R. K., Oliveira, F. B., Hryniewicz, L. G., Sant'Anna, A. de S., \& Moura, L. C. (2020, abril). Liderança feminina: percepções, reflexões e desafios na administração pública. Cadernos EBAPE.BR, 18(2), 406-423.

Mountian, A. G., Gomes, G., \& Carvalho, L. (2020). Discriminação contra refugiados no mercado de trabalho: falha de informação e o papel das políticas públicas. In Anais do 440 Encontro de Gestão de Pessoas e Relações de Trabalho, Curitiba, PR.

Nguyen, M. T. (2012). The gift of freedom: War, debt, and other refugee passages. Durham, Carolina do Norte: Duke University Press. 
Öztürk, C., \& Pickel, G. (2019). Islamophobic right-wing populism? Empirical insights about citizen's susceptibility to islamophobia and its impact on right-wing populists' electoral success: Eastern Europe in a Comparative Perspective. Religion \& Society in Central \& Eastern Europe, 12(1) 39-62.

Pereira, F. O., \& Oliveira, J. S. A. (2017). Intersecção entre raça, gênero e imigração no mercado de trabalho: um estudo com mulheres haitianas na cidade de Maringá, Paraná. In Anais do 6o Encontro de Gestão de Pessoas e Relações de Trabalho, Curitiba, PR.

Pereira, G. L., \& Abreu, M. E. C. (2016). Transformando o "intruso" em "incluso": xenofobia e discriminação na acolhida de imigrantes no Brasil. In Grupo de Assessoria a Imigrantes e a Refugiados (Org.), Múltiplos olhares: migração e refúgio a partir da extensão universitária. Porto Alegre, RS: Faculdade de Direito da UFRGS.

Pringle, R. (1988). Secretaries talk: Sexuality, power and work. Crows Nest, Austrália: Allen \& Unwin.

Ribeiro, D. (2010). O povo brasileiro. São Paulo, SP: Companhia de Bolso.

Rizkalla, N., \& Segal, S. P. (2019). War can harm intimacy: consequences for refugees who escaped Syria. Journal of Global Health, 9(2), 1-10. Retrieved from https://dx.doi.org/10.7189\%2Fjogh.09.020407

Santos, C. M. M., Tanure, B., \& Carvalho, A. M., Neto. (2014). Mulheres executivas brasileiras: $\mathrm{O}$ teto de vidro em questão. Revista Administração em Diálogo, 16(3), 56-75.

Sayad, A. (1998). O que é um imigrante. In A. Sayad. Imigração ou os paradoxos da alteridade (pp. 45-72). São Paulo, SP: EDUSP.
Silva, C. A. S. (2013). A política brasileira para refugiados (19982012) (Doctoral Dissertation). Universidade Federal do Rio Grande do Sul, Porto Alegre, RS.

Spiegel, P. B., Checchi, F., Colombo, S., \& Paik, E. (2010). Necessidades de cuidados de saúde das pessoas afetadas por conflitos: tendências futuras e estruturas em mudança. The Lancet, 375(9711), 341-345.

Tedesco, J. C. (2010). O gênero na imigração: redefinições de papéis e dinâmicas étnicas. In Anais do 9o Fazendo Gênero - Diásporas, diversidades, deslocamentos. Florianópolis, SC: UFSC.

Tsui-Auch, L. S. (2005). Unpacking regional ethnicity and the strength of ties in shaping ethnic entrepreneurship. Organization Studies, 26(8), 1189-1216.

Turner, R. (2019). Migrants and refugees: improving health and wellbeing in a world on the move. PLoS Med, 16(7), e1002876. Retrieved from https://doi.org/10.1371/journal.pmed.1002876

Versiani, F., \& Carvalho, A., Neto. (2018). Trabalhadores imigrantes e trabalhadores brasileiros em São Paulo: a influência recíproca entre os "desviantes" e os "normais". In Anais do 42o Encontro da ANPAD, Curitiba, PR.

Villen, P. (2015). Imigração na modernização dependente: "braços civilizatórios" e atual configuração polarizada (Doctoral Dissertation). Instituto de Filosofia e Ciências Humanas, Universidade Estadual de Campinas, Campinas, SP.

Wodak, R., \& Chilton, P. (Ed.). (2004). Uma nova agenda na análise (crítica) do discurso: teoria, metodologia e interdisciplinaridade.

Thousand Oaks, CA: Sage, 2004.

Hélio Arthur Reis Irigaray

ORCID: https://orcid.org/0000-0001-9580-7859

Professor and Researcher at Fundação Getulio Vargas (FGV EBAPE). E-mail: helio.irigaray@fgv.br

Renata Anderson

ORCID: https://orcid.org/0000-0003-4853-133X

Ph.D. and Master in Business Administration, with a focus on Social and Environmental Management and Health from Fundação Getulio Vargas (FGV EAESP), with a master's exchange at ESADE Business School (Barcelona); Specialist by CEAHS from FGV EAESP in Hospital Administration and Health Systems; Bachelor of Nursing from PUCCAMP; Guest Editor at the Journal of Humanitarian Logistics and Supply Chain Management, in the special issue "Preparing the Humanitarian Supply Chain for Epidemics and Pandemics Response"; She was a professor at Northern Kentucky University; Researcher at Health In Harmony, Portland- United States of America. E-mail: mrs.renataanderson@gmail.com

Flávio Vellasquez

ORCID: https://orcid.org/0000-0003-3745-0104

Master's degree in Administration from Fundação Getulio Vargas (FGV EBAPE); Invited Professor at UNIGRANRIO Graduate School.

E-mail: flavio.vellasquez@fgv.br

Fernando Filardi

ORCID: https://orcid.org/0000-0002-9333-0871

Professor and Researcher of the Master in Administration at IBMEC/RJ; Professor and Researcher at UNIRIO. E-mail: fernando.filardi@professores.ibmec.edu.br 